\title{
Envisaging “Our” Nation: Politicized Affects in Minority Language Literature
}

\author{
Lydia Kokkola 1
}

Published online: 1 November 2017

(C) The Author(s) 2017. This article is an open access publication

\begin{abstract}
This paper draws on two forms of cognitive studies to examine how a minority language literature cultivates feelings of in-group belonging. The minority in focus are the Tornedalingar: Swedish nationals who live near the Torne River which marks the border with Finland. The official language of the Tornedalingar is "Meänkieli" which literally translates as "our language". The first part of the paper draws on the work of Sara Ahmed to show that emotions are both embodied and culturally specific, the second half of the paper takes this argument a step further, drawing on studies of children's poetry by Karen Coats and Debbie Pullinger to show how the rhythmical patterns of Meänkieli poetry entrain children into a culturally specific sense of belonging.
\end{abstract}

Keywords Meänkieli · Swedish children's literature · National minorities · Minority languages

In The Cultural Politics of Emotion, Sara Ahmed explains how "emotions work to shape the 'surfaces' of individual and collective bodies. Bodies take the shape of the very contact they have with objects or others" $(2014$, p. 1). This shaping of the body

Prof. Lydia Kokkola is Head of English and Education at Luleå University of Technology, Sweden. Her main areas of research are reading in a foreign language, adolescent sexuality and Holocaust studies. Kokkola's most recent monograph-Fictions of Adolescent Carnality: Sexy Sinners and Delinquent Deviants-was published by John Benjamins.

Electronic supplementary material The online version of this article (http://doi.org/10.1007/s10583017-9340-8) contains supplementary material, which is available to authorized users.

Lydia Kokkola

lydia.kokkola@1tu.se

1 Luleå University of Technology, Luleå, Sweden 
takes place through interactions with objects, people and words. In Queer Phenomenology, Ahmed (2006) uses the example of weights in a gym to show how the orientation of a body towards or away from these lifeless objects impacts on not only the shape of the body, but the very way of being in the world. Orienting the body towards the weights can create stronger muscles, reduce pain and increase feelings of well-being; orienting the body in a different way can damage muscles, produce pain and lower levels of well-being, and orienting the body away from the weights would produce no change. Equally, orienting the body towards some groups of people and away from others affects self-perception, and so on. In The Cultural Politics of Emotion, Ahmed goes on to treat affect as a deeply embodied act as she examines how words produce emotion. More specifically, she examines the role of affect in performing culture, and thus the political nature of emotion.

This paper begins by drawing on Ahmed's argument to examine the affects involved in passing on a minority culture, paying particular attention to her observations about the embodied nature of language and emotion. The minority concerned are the Tornedalingar: ${ }^{1}$ Swedish nationals who live near the Torne River, which marks the border with Finland. The official language of the Tornedalingar is Meänkieli. Recent years have seen a rapid expansion in publications in this language of which three are examined here. The first is a short, bilingual novel, Tuu, tuu, tupakkarulla by Kristina Lantto-Toffe (1994), which introduces readers to the violent language policies in the region in the first half of the twentieth century. Тиu tuu tupakkarulla literally translates as "come, come, roll of tobacco", which is the first line of a popular Finnish lullaby. I contrast the version of this song in LanttoToffe's novel with the original, and then identify similar patterns in other regional variants of traditional Finnish songs, rhymes and language games in Moron, Moron, Ostaks' Poron [Morning, Morning, D'you Wanna buy a Reindeer?] (1986), a collection of oral language games, rhymes and riddles collected and edited by Monica Johansson and Mona Mörtlund, and in Meänkieli ja Mettä Mimmi [Our Language and Forest Mimmi] (2001), a collection of rhymes and songs used in daycare centres in the region. My aim is to show how the stress patterns and rhythms entrain the young child into Meänkieli language and culture. I begin by outlining some key features of the languages and the language politics of the region, so that the political character of these materials is comprehensible. I then identify ways in which the Meänkieli texts promote entrainment and feelings of in-group belonging.

\section{The Tornedalingar and Meänkieli Literature}

The border between Finland and Sweden, the Torne Valley, is the birthplace of Meänkieli, which literally translates as "our language". Linguistically, Meänkieli is a dialect of Finnish with an unusually high number of calques from Swedish and also some from Sámi. Until recently, it was a purely vernacular language that was

\footnotetext{
1 The official English term for this group is "Torne Valley Finns", a term I find unhelpful as it implies that they are Finnish citizens. There are indeed Finnish citizens living in the Torne Valley, but the people I am referring to are Swedish citizens. Following the Meänkieli activist and scholar Birger Winsa's lead, I use the Swedish term untranslated.
} 
subject to aggressive language policies which endeavoured to suppress its use (Elenius, 2004; Winsa, 1998). From the 1920s onwards, school children could be punished for speaking Meänkieli, to the extent that, in 1957, a law forbidding teachers from depriving children of food or physically beating them was deemed necessary (Slunga, 1965; Kenttä and Weinz, 1968). Even though this law officially ended corporal punishment, negative attitudes towards the use of Meänkieli lingered long afterwards, and many parents chose not to pass on the language to their children. Politically, since 2002, Meänkieli has been recognized as the official language of the Tornedalingar-one of Sweden's five official national minoritiesand children are entitled to education in the language. Whereas all children in Swedish schools are entitled to support for their home language, the National Minorities are also entitled to language support if their grandparents spoke the language but "chose" (due to the aforementioned policies) not to pass it on to their children.

Until very recently, Meänkieli was referred to as "Tornedalsfinska" (Swedish for "Finnish of the Torne Valley"). Both terms have had negative connotations as they express the idea that "this is just our way of speaking", as though it were improper. They also signal a slightly different allegiance: whereas "Finnish of the Torne Valley" implies that these Swedish nationals are speaking the language of the neighbouring country, "Our language" indicates a distinct group.

The recognition of Meänkieli as a distinct language has resulted in desktop publishing by grassroots activists who wish to promote Torne Valley culture and language. The informal nature of this activity makes it difficult to ascertain precisely how many books are available in Meänkieli, not least because what constitutes a "book" or "publication" is not self-evident. One of the texts I examine here, Astrid Kruukka's collection of songs, rhymes and language play produced or recalled by children, Meänkieli ja Mettä Mimmi [Our Language and Forest Mimmi] (2001), ${ }^{2}$ is simply a ring-bound collection of 16 sheets of A4 card. It is available for loan from public libraries in Norrbotten (the region in which Meänkieli is spoken), but has no ISBN number. Aina Stålnacke's Missa: Kertomus Liinan viishasta kissasta [Missa: A story about Liina's wise cat] (1989), a booklet printed on 10 sheets of A3 paper, stapled down the centre with a thicker sheet forming the cover, does have an ISBN number. It was produced by the Förlaaki Kaamos publishing house, which ensured that copies were available beyond Norrbotten's borders, for instance in the Swedish Institute for Children's Literature. The far more professionally executed Moron, Moron, Ostaks' Poron [Morning, Morning, D'you Wanna buy a Reindeer?] (1986), a collection of songs, rhymes, riddles and language games collected and edited by Monica Johansson and Mona Mörtlund, was commissioned by the School Board and Social Board of Norrbotten and was issued directly to children, as well as schools and kindergartens, free of charge. It too has an ISBN number but is not registered in the Children's Literature Institute's collection, and is listed as being in Swedish in the Norrbotten library system. There are also novels like Annika Korpi's Hevonen Häst [Horse Horse] (2003), which incorporate Finnish and/or Meänkieli into an otherwise Swedish text. This particular novel uses one of the bilingual rhymes I

\footnotetext{
${ }^{2}$ All translations into English are my own.
} 
discuss towards the end of this paper in its title, but is contextualized so that a Swedish speaker will have no difficulties following it.

These kinds of publishing practices make it difficult to determine exactly how many books have been produced in Meänkieli. I estimate that the total number of books in Meänkieli is about 160, of which approximately ten are dictionaries and ninety are for children (see Kokkola forthcoming for an overview of these books). These guesstimates exclude novels like Korpi's, where only a few words or expressions are used in an otherwise Swedish text (a much more common practice in novels for adults by regional writers). This focus on writing for children reflects both the desire to pass on the language and the demand for material produced in Meänkieli to fulfil the legal educational requirements. They provide a conduit for passing on the region's culture and language, and promote positive attitudes towards in-group belonging. These are politically motivated publications: their very existence rejects the harsh language policies of the region in the first half of the twentieth century.

\section{Suppressing Minority Languages}

A particularly unsavoury chapter in Sweden's history is the promotion of eugenics in the early twentieth century. In 1922, Statens institut för rasbiologi (SIFR) [The State Institute for Racial Biology] was founded in Uppsala, the home of the oldest university in Scandinavia. The SIFR was intended to examine the impact of biology and environment on criminal behaviours, mental illnesses and alcoholism, all of which were assumed to have a racial dimension. Much of the research under the leadership of the Institute's first director, Herman Lundborg, was devoted to documenting the physical racial features of the five groups that would later be declared the national minorities of Sweden, in no small part as an act of apology for the work of the SIFR and the policies based on its so-called research findings. Lundborg and his colleagues were particularly active in the northern parts of Sweden, where they photographed and collected measurements of the Sámi, Romanies, Finns and Tornedalingar to suggest that these peoples were inherently inferior. ${ }^{3}$ Policies, including forced sterilization and the suppression of minority languages, developed from these findings as the state endeavoured to turn these undesirables into "proper", Swedish-speaking citizens.

Workhouses played a key role in the enactment of the Swedish-only policy and concerted attempts to destroy other national languages. I use the term "workhouse" as it is a literal translation of the Swedish "arbetsstuga", but within the Anglophone context "residential school" captures the purpose of these institutions more closely. These institutions were established across Norrbotten in the first years of the twentieth century (Elenius, 2006). They were initially a humane response to the extreme poverty of the region, but rapidly developed into a politicised institution within the school system. Children from impoverished backgrounds lived in the

\footnotetext{
3 The fifth group designated a national minority are Jews. So few Jews live in Norrbotten that the nearest synagogue is in Stockholm - a ten hour train journey away.
} 
workhouses where they received free board and lodging and often clothing whilst they attended school. In the legislation concerning the workhouses in 1913, there is no mention of the language situation in the region, but by the mid-1920s, the situation had changed. Lars Elenius cites rules from 1924 stating that "within Finnish speaking areas, the use of Swedish as the language of the workhouses must be ensured" (a formalization of the previous year's instruction that "staff in the workhouses within Finnish speaking areas must always use Swedish with the children in everyday conversation, also during breaks" [2006, n.p.]).

Tuи, tuu, tupakkarulla provides insight into the lived experience of workhouse children. Seven-year-old Elina's Laestadian parents are forced to send her and her sister Enni to a workhouse in a small town far away from their home. (Lars Levi Laestadius [1800-1861) was a revivalist Sámi preacher who inspired the formation of a sect within the Lutheran church.) The story does not explain why the girls are sent away, but there is clearly not quite enough food to feed the whole family and another baby is on the way. Their mother is tearful about their departure, and readers learn that some children are sent to the workhouse because there are no schools near their homes. When Elina first arrives at school, she cannot understand Swedish and yet she is forbidden to speak Meänkieli. The outdoor privies become the only safe space where the children can speak Meänkieli, and they gather there to swear and gossip. Elina's inability to comprehend Swedish is incorporated into the plot. In one particularly horrific scene, she is force-fed an unfamiliar food from a plate covered in vomit. Eventually she is rescued by the Laestadian cook who says something in Swedish to the teacher that ends the torture, and the pair then share a cosy moment in the kitchen speaking Meänkieli and eating bread and milk. Readers never know what the cook said and, like Elina, have to wait for a translation from Enni to learn that she has been eating kidney beans. Other moments of joy include attending Sunday school where they eat cake and sing, but like the moment with the cook, the joy is associated with speaking Meänkieli.

The story is only 40 pages long, but the book contains the same story in both Meänkieli and Swedish, depending on which way up the book is held (Fig. 1). This fusion of languages within the covers of one book reflects the bilingual lives of many Tornedalingar. The novel begins and ends with Elina singing the titular lullaby. The use of the same image on both sides of the central spread (one in the direction of the language that is being read, the other inverted in the direction of the other language) could be read as a celebration of Elina's capacity to sing songs from both traditions. However, since Elina is clearly much happier at home with her family, singing in Meänkieli, I think this image also captures the upside-down world in which children are expected to communicate in a language they do not know. The narrative clearly equates the Swedish-speaking world with threats and misery, whereas the Meänkieli world is associated with companionship, song and laughter: emotions are clearly politicized. 


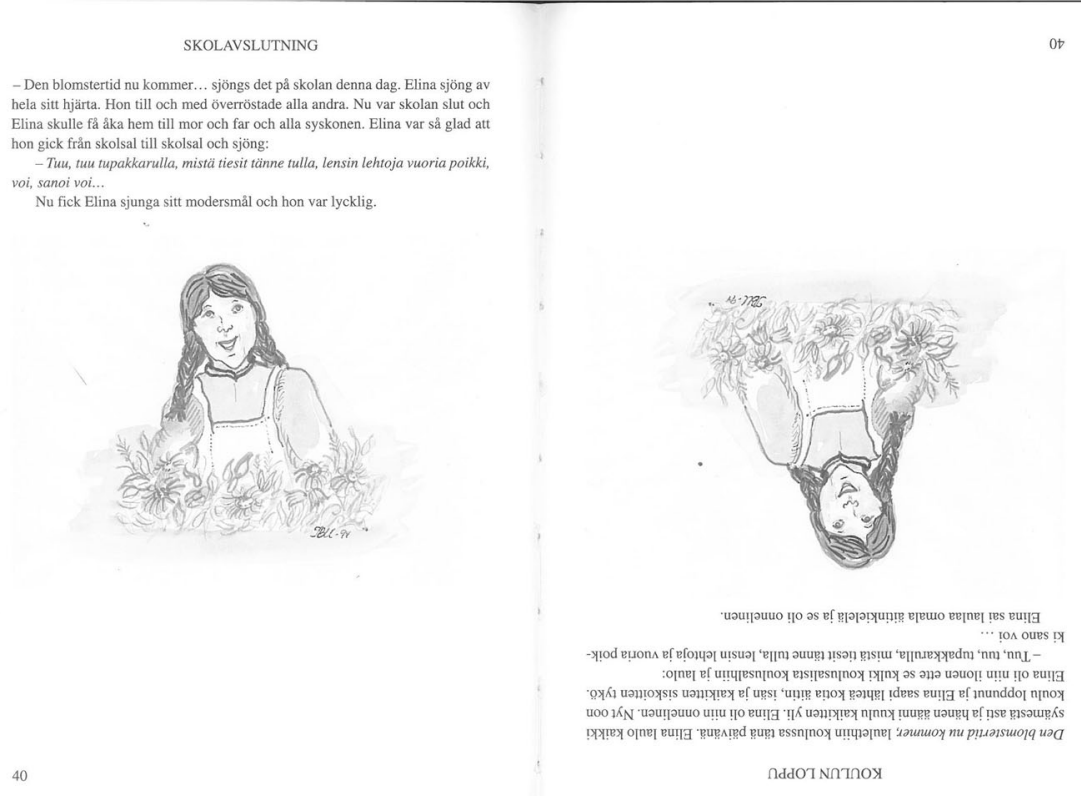

Fig. 1 Centre page Tuu, tuu, tupakkarulla

\section{The Cultural Politics of Emotion}

Ahmed begins The Cultural Politics of Emotion with a citation from a British National Front poster. She picks up on how this language aligns "“you' with the national body. In other words, the 'you' implicitly evokes a 'we', a group of subjects who can identify themselves with the injured nation", and she demonstrates that "the 'we' of the nation is only available to white Aryans" (2014, p. 2). Although Ahmed does not cite Lakoff and Johnson, whose seminal work, Metaphors We Live By (2008), paved the way for cognitive approaches to the study of literature, her approach is based on the same principles. Lakoff and Johnson used the then emerging discipline of corpus linguistics to reveal metaphors and metonyms evident in common collocations (for instance, the idea that time and money are related is evident in the use of identical structures such as "spending" time and money). They argued that this exposed patterns of human perception, an idea that is a cornerstone of cognitive poetics. Ahmed uses a similar method to expose the images that underlie the rhetoric of public texts ranging from National Front posters to official Government documents. Taking her argument beyond that offered by Lakoff and Johnson, Ahmed examines the emotional responses that are evoked by these images, noting how their power increases with repetition.

Ahmed uses three case studies-the return of the "lost" Aboriginal children to their families, responses to terrorism in the wake of 9/11, and asylum-seeking and immigration policies in the United Kingdom - to argue that emotions are primarily cultural expressions rather than psychological states. This idea is not unique: in the 
nineteenth century, William James and Carl Lange put forth a theory (now known as the James-Lange theory) that proposed that we first observe our bodily responsesfor instance, that we feel thick in the throat and start to cry-and only then register and label the emotion as feeling sad. Ahmed takes this observation further to note that these attributions of emotion are culturally defined. Shame is perhaps the most obviously culturally specific emotion: all humans experience shame, but the triggers of shame (e.g. practices surrounding eating, defecating and covering the body) involve culturally specific taboos which give rise to feelings of shame when they are breached. Ahmed's analyses of varied texts relating to the three political events mentioned above highlights the public nature of emotions, and how cultural forces shape the expression of feeling. Through figurative language that insists on creating and marginalising "others", the language of emotion creates in-groups and outgroups. More specifically, Ahmed unveils the influence of emotions on both individual's bodies and communities of bodies in relation to the rhetoric of nationhood.

The role of children's literature in forging, promoting and sustaining notions of nationhood cannot be overstated. Ever since John Stephens' seminal Language and Ideology in Children's Fiction (1992) heralded scholarly engagement with the ideological beliefs encoded in the language of books for children and adolescents, critics have examined how national ideals are represented and disseminated, to the extent that such studies have dominated the field. A quick categorization of the books appearing on Routledge's website listing books in their Children's Literature and Culture series (the longest running in the field), reveals that the majority of titles (69/131) relate to this topic. These include studies of imperialism, national literatures, minority groups within a nation and the process of nation formation. There are also collections which place the nation building of different parts of the world alongside one another and which take disembodiedness of nationhood in the digital era into account. Despite their many disparities, all these works identify key images, beliefs and goals that have distinguished nations from one another. Many of them pay close attention to the language of the literatures they discuss. What none of them do, however, is investigate how the rhythms of the national languages contribute to the formation of emotions. Ahmed provides us with a framework for examining the interplay between language and a sense of nationhood, but I wish to go further and draw on more recent work within cognitive poetics to try to understand the emotional impact of Meänkieli poetry and songs for children.

The very name of the language_- "Meänkieli" (our language)—signals the politics that Ahmed endeavours to uncover in her study, as it indicates that there is an "us" who speak "our language"; a unified "us" who are not like "them". In reality, Tornedalingar are a very heterogeneous group, less than half of whom speak Meänkieli and not even all of those who do speak the language think that it should be taught in schools, as they would rather see that time devoted to the teaching of international languages such as English. By choosing the term "Meänkieli", activists have found a means to simplify the complex politics of the region and create a clear sense of an in-group and an out-group. Those who claim that they do not speak Meänkieli, just "Tornedalsfinska", are signalling an emotional response to the perceived exclusivity of "Meänkieli": they do not feel they belong to the 
inner core who feel most at home speaking the regional language. They are happy to speak Finnish in their own way, but their dominant language is usually Swedish. Meänkieli literature for children, I suggest, also endeavours to impose a sense of an in-group identity.

\section{“Our" Culture: Forging In-group Identity}

In applying Ahmed's idea that language engenders culturally specific emotions, a straightforward discussion of the metaphors of Meänkieli literature for children reveals little of value: the distinctions from mainstream Swedish or Finnish culture are impossible to detect in this way. However, when I compare the Meänkieli version of Lantto-Toffe's novel with her own Swedish version, or the Meänkieli songs in the novel and in Johansson and Mörtlund's collection with the traditional Finnish versions of these songs, the promotion of positive in-group identity becomes easier to detect.

The simplest way to show this difference is to examine the illustrations of Tuu, tuu, tupakkarulla. The novel is illustrated with black-and-white ink sketches by Inga-Britt Uusitalo. Both language versions begin and end with an illustration of Elina singing "Tuu, tuu, Tupakkarulla" (see Fig. 1); in between, the majority of the illustrations are different. The contrasts emphasise different affects: the illustrations on the Swedish side emphasise the institutionalisation of the girls' lives, whereas those on the Meänkieli side emphasises connections to home. For instance, the illustration accompanying the Swedish text about Elina cleaning the outdoor privies is of a pail, a scrubbing brush and the rags which the text informs us "froze to ice" (Lantto-Toffe, 1994, p. 14). The image emphasises the tough, unpleasant tasks Elina was expected to perform "even though she wasn't quite eight years old" (LanttoToffe, 1994, p. 14). The illustration of the Meänkieli version, in sharp contrast, depicts two girls smiling and whispering to one another inside the privy with the door flung open, whilst a boy waits outside with a huge grin on his face (LanttoToffe, 1994, p. 16). Behind them, the birch tree is in leaf, and there are foxgloves growing beside the wall. It is an idyllic scene of friendship and community (Fig. 2).

Similarly, the description of the long journey to the school is illustrated on the Swedish side with a picture of the dangerous route along wooden planks through the swamp where "Dad told us that our best milk cow had drowned in the mire" (Lantto-Toffe, 1994, p. 7), whereas the Meänkieli version is illustrated with a picture of Enni and Elina sitting on their father's bicycle as he accompanies them as far as the main road (Lantto-Toffe, 1994, p. 6). In both these examples, the narrative is identical-they are exact translations-but the images foreground very different aspects of the story. The pattern is consistent throughout the book: the images in the Meänkieli version celebrate family ties and cultural resistance; the illustrations of the Swedish version expose the horrors of workhouse life.

Since the language of the two versions of the novel (both by Lantto-Toffe) is almost identical, the very rare instances where differences appear are all the more significant. They relate to church services and greetings. The man who drives the girls to school in his car is greeted with "God's blessings" using a Laestadian- 


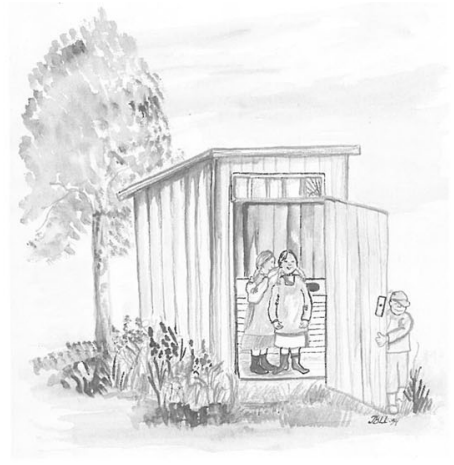

Useasti ulkohyysikässä puhuthiin ommaa kieltä

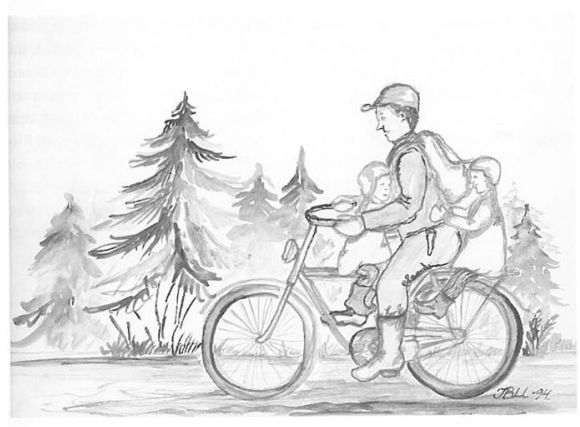

Enni sai istua pakettihollarissa

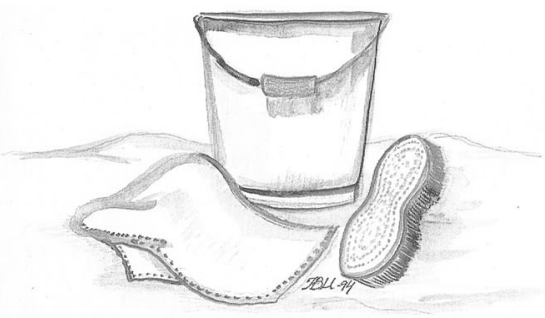

Elina fick hjälpa till att skura dassen

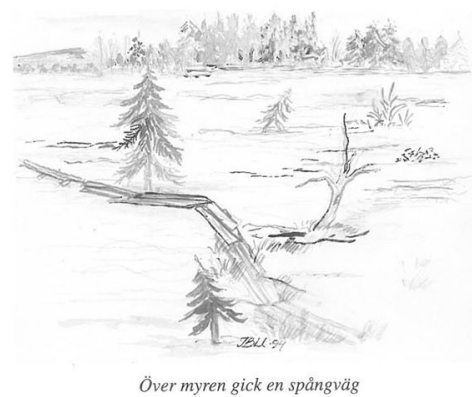

Fig. 2 Cleaning the outhouse \& leaving home

specific greeting, but in the Swedish version the greeting has to be glossed. Similarly, the Meänkieli description of Sunday school assumes the reader will recognise Laestadian practices, but the Swedish version adds additional explanation. The difference is very subtle, but it indicates a distinction between the in-group who are expected to be familiar with Laestadian practices and an out-group who need to be explicitly told.

The most significant difference between the languages, however, is not between the Meänkieli and Swedish versions of the novel, but rather between the Meänkieli version of the titular lullaby and the original Finnish version. In the next section, I examine not only the lullaby in Lantto-Toffe's novel, but also the rhymes and language games of Moron, Moron Ostaks' Poron and Meänkieli ja Mettä Mimmi to suggest that the shifts in the language and content are very specifically situating the language in its geographical location. More importantly, drawing on the work of Karen Coats and Debbie Pullinger, I suggest that the rhythms of Meänkieli music connect body and mind as they entrain children's bodies into "our" language and culture. 


\section{The Music of the Torne Valley}

Tuи, tuи, tupakkarulla is a lullaby with a reference to a specific road in southern Finland in the opening verse. In this region, tobacco used to be cultivated in small quantities on the edges of grain fields. When the crop was harvested, the leaves were rolled into a bundle that resembled a new-born baby wrapped in a blanket. "Tupakkarulla" is thus a term of endearment although, like many cradle-songs, the rest of the song is a mixture of political commentary, ambivalent feelings and mild threats. The opening lines ask the baby where it came from, and the baby replies that s/he came along the road from the old capital, Turku, to Häme (a region in central Finland). Known as the road of the oxen, this was also the route taken by the Swedish nobility when they came to hunt. The baby is asked how it recognized this particular home, and the baby provides a detailed description of the gate. The final three stanzas contain complex language play, including anthropomorphising the oven, and begging the child to sleep. The melody is very simple and slightly melancholic as, like many Finnish songs, it is sung in D-minor to 2/4 rhythm. The metre is known in Finnish as "Kalevala metre" after the national epic; it is quintessentially Finnish. The first syllable of Finnish words is always stressed, so that the main pattern is trochaic. (Swedish, like English, is predominantly iambic.) The classic Kalevala metre is trochaic tetrameter (i.e., it is formed of four trochaic feet). With the exception of the first line, "Tuu, tuu, Tupakkarulla" follows this classic pattern. "Tuu" is a shortened form of "tule": "come". Abbreviating the word creates a spondee, which allows the singer to draw the attention of the audience. The other verses all start with trochees. The shortening of "tule" to "tuu" also emphasises the regional specificity of the song as this kind of shortening is a typical feature of Turku dialect and is unusual in the north and in Meänkieli. The version in Lantto-Toffe's book, even though it starts with the same first lines, is very different.

The novel begins and ends with the first four lines of the song. The first two, which ask the baby where it came from, are identical, but the baby's reply removes the reference to the road of oxen. Instead, this baby "Lensin lehtoja, vuoria poikki/ voi, sanoi voi" [I flew over the copses and through the mountains/'Oh dear!' said the butter]. The words are the same as they would be in standard Finnish, and the reference to copses and mountains signals that the baby travelled northwards (there are no mountains in southern Finland and copsing — harvesting the shoots and leaves of trees as animal fodder-is rare in the north). The pun- "voi" is both the word for butter and a mild expression of concern-resembles the language play in the final three verses of the standard version of the song, although this particular pun is not used there. In terms of rhythm, the change seems even more significant. The stressed syllables are underlined here: "Len-sin leh-to-ja, vuor-i-a poik-ki/voi, sanoi voi". Although the words are standard Finnish, note that the stress pattern is no longer trochaic. Words like "lehtoja" are dactylic and the final line could most easily be sung by extending the vowel sound "oi" to form an iambic pattern. In short, the Torne Valley version no longer fits the original Finnish tune. 
Unfortunately, I have been unable to find anyone who can sing this particular version of the lullaby, so I am not certain how it is stressed when sung, but there are at least two other versions which are sung in the Torne Valley, one of which has lyrics that are very similar to the standard version and almost identical for the first stanza. The difference is the question "How did you know...?" where the standard version omits the second person pronoun ("you"). In standard Finnish, pronouns are often omitted as the verb form carries the information. Swedish, by contrast, does not change verb forms according to the subject, and so the inclusion of pronouns is considered essential. Meänkieli speakers tend to include pronouns in contexts where Finnish speakers would not, as is the case in the version collected by Johansson and Mörtlund: Moron, Moron, Ostaks' Poron [Morning, Morning, D’you Wanna buy a Reindeer?] (1986). This collection also includes a variant titled "Tullan, Lullan, Tupakkarullan". Note how the spondee, "Tuu, tuu", has been replaced by words of two syllables. "Tullan" is Meänkieli for "I come/am coming" and is trochaic; "lullan" is a rhyming nonsense word which has the same rhythm. The melody has a 2/4 beat in the same D-flat key as the standard Finnish version, despite the very strongly marked Meänkieli characteristics of the lyrics. In contrast, the version with more traditional lyrics has a $5 / 4$ rhythm and is sung in E-minor. It is as though keeping the Finnish lyrics demands a new rhythm in order to become part of Torne Valley culture, whilst changing the words makes retaining the standard Finnish rhythms more palatable.

This reframing of traditional Finnish songs is a fairly common feature of music from the Torne Valley. In the 1960s and 1970s, Wäinö Ruottinkoski, who referred to himself as a speaker of Tornedalsfinska from Gällivare, collected and transliterated folksongs from the Torne Valley with the aid of Airi, his Finnishspeaking wife from central Finland. According to their daughter, Maria, their main goal was to preserve the Meänkieli tunes and traditions (personal communication). Wäinö would record Tornedal folk singers and produce the music in written form. Sadly, due to the belief prevalent during this era that Meänkieli was an incorrect form of Finnish, the words of the songs were often "corrected" by Airi so thatalthough they do contain many dialect words-they resemble standard Finnish more closely than those of the original singer. "Tuu, tuu, Tupakkarulla" is not one of the songs in Ruottinkoski's collections, but there are many other songs which show a change in the stress pattern if one compares the traditional Finnish melody with the Tornedal melody. The change can be thought of in terms of dance steps. The Kalevala metre results in tunes that are danced to the foxtrot or Finnish tango- - the most common dances in the outdoor Finnish dance halls that remain a popular feature of rural summer life. The Finnish version of the waltz-known as the huтрра- has an even heavier emphasis on the first step: one almost stamps the floor as one would in a polka. The songs in Ruottinkoski's collections are gentler, the rhythms flow in a manner that resembles the waltz traditions within Swedish and central European music rather than the humppa or Finnish tango. They also tend to make less use of melancholic minor keys, and thus have a decidedly less Finnish quality. I suggest that these tunes are picking up Swedish cadences, and the hybrid form that arises is also a common feature of Meänkieli children's songs, rhymes and language games. Sharing these rhythmical pieces creates a sense of community and entrains the child's body into Torne Valley culture. 


\section{Songs and Rhymes for and by "Our" Children}

Moron, Moron, Ostaks' Poron (1986) is a collection of oral language games, rhymes and riddles from the Torne Valley. It was commissioned by the School Board and Social Board of Norrbotten from Monica Johansson and Mona Mörtlund, who collected oral folklore from five municipalities in the Torne Valley in 1984-1985. This early work does not use the term "Meänkieli", although the Introduction endeavours to create a sense "us" as Johansson and Mörtlund identify reasons why children are not learning the language as much as they used to. Noticeably, the policies of language suppression are omitted, and factors such as the declining population and presence of television are emphasised. The collection was given directly to Torne Valley children as well as to schools and kindergartens, free of charge. Johansson and Mörtlund note that, although they have included only one version of each song or rhyme, this version should not be considered more correct than any other (1968, p. 5). For some of the pieces, standard Finnish equivalents exist, but the collection focuses on works that are regionally specific, often incorporating loan words from Swedish or Sámi as well as dialect terms. Fifteen years later, Astrid Kruukka collected rhymes and language games from children in daycare units as part of a regional project on "Meänkieli in daycare, schools and youth groups". The rhymes in Kruukka's "publication", Meänkieli ja Mettä Mimmi [Meänkieli and Forest Mimmi] (2001)—in practice, 16 photocopied sheets of children's drawings and rhymes on A4 paper, bound with a ring-binder-nearly all have clear antecedents in Johansson and Mörtlund's collection. (Mimmi is a girl's name, and in this collection Mimmi is a frog.) Kruuka's collection contains a series of dual language list poems recited by "Astrid" in March 2001. Astrid refers to her rhymes as being alternatives for the version that appears in Johansson and Mörtlund's (1986, p. 17) collection. The words in the left column (Hevonen, Pappi, Suola for Johansson and Mörtlund; Kissa, Hattu, Lehmä for Astrid's version in Kruukka (2001, p. 9)) are in Finnish/Meänkieli. The words in the right column (häst, präst or katt, hat) are in Swedish. The English translation appears in square brackets: ${ }^{4}$

\begin{tabular}{llll}
\hline Hevonen - häst & [horse] & Kissa - katt & [cat] \\
Pappi - präst & [priest] & Hattu - hat & [hat] \\
Suola - salt & {$[$ salt] } & Lehmä - ko & [cow] \\
Kylmä - kallt & [cold] & Kenkä - sko & [shoe] \\
Mallas - malt & [malt] & Susi - varg & [hay] \\
Kaikki - allt & [everything] & Vihanen - arg & [angry] \\
\hline
\end{tabular}

\footnotetext{
${ }^{4}$ It is worth noting that similar rhymes are often incorporated into teaching Finnish to Swedo-Finns. Swedo-Finns are Finnish nationals whose first language is Swedish. They comprise approximately $6 \%$ of the total population, although there are still areas (primarily coastal areas) where the Finnish variety of Swedish is the main regional language.
} 
The Swedish words form rhyming couplets where the rhyming word is a single stressed syllable. In Johansson and Mörtlund's collection, the Finnish/Meänkieli words, with the exception of dactylic "hev-o-nen", are comprised of a single trochee. The ensuing -/- stress pattern of each line resembles neither the classical Finnish trochaic rhythm nor the Germanic iambic rhythm found in Swedish (and English). The rhyme in Kruukka's collection is almost identical in terms of rhythm, except that the dactyl appears at the end. Kruuka's collection contains several pages with this kind of poem, not all of which follow the pattern quite as strictly, although this is the rhythmical pattern that dominates.

Hevonen - Häst and other bilingual rhymes formed from pairs of words can also be found in the Swedish speaking regions of Finland. Although the content appears didactic, as it encourages children to differentiate between the languages even as it celebrates their multilingualism, the rhythm pattern rocks the child into a middle ground between the two languages. Space does not permit a full discussion of the differences between the Swedish spoken in Finland and the varieties spoken in Sweden but, whereas Finnish speakers respond most strongly to the calques (i.e. vocabulary drawn from Swedish) that distinguish Meänkieli from standard Finnish, Swedish speakers on both sides of the border react most strongly to the rhythm. They refer to one another's speech as "singing", and this is largely due to the influence of Finnish rhythm on Finland-Swedish.

In a discussion of the embodied nature of reading, Margaret Mackey (a Canadian) includes an anecdote about her experience as a teacher in Britain.

I soon discovered that, while I could keep my own pronunciation of words, I was a much more successful communicator with these students if I adopted British cadences. For example, the rise and fall of the voice that flags a question is different in Britain than in North America, and my students were much better able to hear the interrogative element of my question when I shifted my stress patterns. (Mackey, 2017, p. 185)

I suggest that something similar is happening when songs and rhymes from the Torne Valley distinguish themselves from standard Finnish rhythms. This is even clearer in the rhymes and games that are solely in Meänkieli. As their bodies move to the rhythm of Meänkieli, the children are made "to feel at home in their own bodies as well as in their social, languaged worlds", more specifically the cultural language of their regional home (Coats, 135). This connection between the rhythms of the language and the movements of the body-entrainment-has been shown to be beneficial for children's social development.

\section{Embodying Meänkieli: Entrainment and Poetic Rhythms}

Entrainment, "a term which refers to the universal tendency for rhythmic processes to adjust to each other" (Pullinger, 2017b, pp. 141-142), also describes the way in which the body adjusts itself when we listen to music. Not only conscious movements, such as tapping, clapping and stepping, but also subconscious processes, such as our heartbeat and the rate at which we breathe, adjust to the 
rhythms of music. One of the reasons it can feel easier to exercise as a group is that we "fall into phase" with the musical rhythm and the bodily rhythms of those around us. In her discussions of children's bodily responses to the musical elements of poetry, and the language games involving ritualized movements, Debbie Pullinger (2017a, pp. 141-148; 2017b) highlights the way in which the bodily responses affect the emotions and, more specifically, the sense of belonging to a community, as parent and child, or older and younger children, create a shared way of being in the world. Her discussion highlights what Martin Heidegger dubbed "Dasein" and Maurice Merleau-Ponty further developed into the concept of "experience-knowledge". 5

What Pullinger, Heidegger and Merleau-Ponty share is an insistence that the body is not an additional feature in the process of meaning-making, but rather that all meaning is deeply embodied. Knowledge is formed through the body, as Merleau-Ponty explains:

I never know things in their totality, but always from an embodied perspective. Because I am a body, I can only see things from a certain perspective, and yet, because I am a body, I can also experience the thing as being more than that partial perspective. The thing exists "in itself" because it resists my knowing it with total certainty. However, the thing exists "for me" because I always experience it in relation to my own body. (153)

In other words, what we know on a cognitive level can never be separated from the physical body that formed the knowledge. When children learn and repeat rhymes like those cited above, the words are embodied through the rhythm. As Pullinger explains, children's "poetry ... is apprehended through rhythm and through the body. Feeling the rhythm therefore acts as a bridge from feeling the palpable rhythms of the outside world and the rhythms of the human body to feeling the deeper, more elusive rhythms of human life itself" (Pullinger, 2017a, p. 141; see also Clayton, Sager, and Will 2004). Although Pullinger's phrasing echoes with the words of the Michael Rosen poem she is discussing, her words also capture what is happening when adult and child connect through Meänkieli rhythms, and perhaps even more strongly when children play skipping games or other chants with very regular beats.

Johansson and Mörtlund's collection is divided into sections, most of which relate to a bodily action. For instance, there are rhymes for finger-play, counting, choosing teams and circle games. There are rhymes to mark the loss of a baby tooth, for dealing with hiccups and getting on and off an adult's lap. Their meaning is much less relevant than what they do: they acculturate children into a social world of language and touch. Pointing, clapping, bouncing and, just as importantly, the

\footnotetext{
${ }^{5}$ In Being and Time, Heidegger took the ordinary German word - dasein - which is formed of "da" (there) and "sein" (to be), thus "being there" to capture the sense of how time impacts on every aspect of our being. Quite literally, I am already several cells different from the person I was when I began this sentence, but my sense of self is largely unchanged. Heidegger was trying to grasp this seeming discrepancy, and the importance of the lived moment through the concept Dasein. Merleau-Ponty, for his part, developed Heidegger's ideas to try to grasp the relationship between meaning-making and dasein. He used the compound "experience-knowledge" to highlight the role of perception and the senses in understanding the world. To an even greater extent than Heidegger, Merleau-Ponty argued for the embodied nature of knowledge.
} 
implicit mutual gaze encouraged by these songs, connect children to their community. As Karen Coats explains:

Children's poetry is almost always shared communally and is hardly ever done without the involvement of the entire body. Children's poems and songs often have actions to accompany them, gestures that adults teach children to imitate as part of the song. These rhymes are almost always conceptually meaningless... But Swedish neuroscientists Patricia Eckerdal and Bjorn Merker were puzzled as to the utility of this conceptually vacant activity until they realised that teaching children action rhymes was a way of training them to participate in communal ritual behaviour. By interacting with adults to learn the combination of melody, words, and movements that form the practice of action songs, children must participate in shared attention and attune their bodies to the bodies of others. The success of the attunement is in some ways its own reward, but such attunement also performs important neurological functions that require the coordination of multiple areas of the brain that control emotion, language, and movement, resulting in a greater sense of coherence, focus, and control both in one's own body and in a social group. (Coats, 2013, p. 139)

In short, Meänkieli language games and songs, like rhythmical children's poetry everywhere, primarily function as a means of welcoming the child into the community. It excludes Finnish cadences to create a sense of an in-group, even as the vocabulary excludes other Swedish citizens who are seeking to understand the meaning.

Pullinger posits the likelihood of a developmental process in responding to metre: initially, the child needs extremely regular, even repetitive, sound patterns, and thereafter develops a sensitivity to more subtle tonal variations in the language (2017a, p. 143). This suggestion is supported by the rhymes collected from children in Kruuka's Mettä Mimmi, which contain even more repetition and heavy patterning than those collected from adults by Johansson and Mörtlund. Kruuka's collection also contains more nonsense words, invented for the purpose of maintaining the sound pattern.

The more complex cadences are evident in the titular poem of Johansson and Mörtlund's (1986, p. 35) collection:

\begin{tabular}{ll}
\hline Moron, Moron & [g'morning, g'morning] \\
Ostaks' poron & [d'you wanna buy a reindeer?] \\
Hyvä ja halpa & [Good and cheap] \\
Mutta klinkussa jalka & [but with a bend in its leg] \\
\hline
\end{tabular}

As the translation reveals, the appeal of the poem does not lie in its meaning but rather in the heavy sound patterning. "Moron" is a loanword based on the Swedish "morgon". Swedes, especially in the north, often omit the "g" but, when writing it 
as a dialect item, "morron" would be more usual. The emphasis is iambic. The Meänkieli greeting, "moron", emphasises the rolled " $r$ " so that the stress lies between the syllables so that it is neither iambic (as "morgon" is) nor trochaic, as "Päivää" (the Finnish greeting that appears in the second stanza) would be. The effect is almost spondaic, and the natural effect on the pattern of the second line is to create a repetition, emphasising both syllables. The standard Finnish "ostatko" [do you want to buy?] has been reduced to the very informal "ostaks", which ends with a demanding double fricative made with the lips open as the tongue controls the flow of air. Before speakers can make the plosive start to the word "poron" [the reindeer], they must close their lips and may also take in more air. This causes a pause between the words, which also supports the spondaic effect. The final two lines are standard Finnish, but the insertion of the single syllable word "ja" [and] in line three and a three syllable word in the final line interrupts the trochees on either side. The resulting rhythm is neither stereotypically Finnish nor Swedish: it is Meänkieli's own blend.

Interestingly, there is a strong resemblance between this poem and a traditional Finland-Swedish rhyme, which appears to be doing the same thing in the opposite direction. The rhyme includes the word "poron" which, as in the previous example, can mean "the reindeer", but can also refer to coffee grounds.

Gu'moron, gu'moron

Stick näsan i poron

å ta åpp den $\mathrm{i}$

övermoron

(Traditional) [g'morning, g'morning]

[stick your nose in the coffee grounds]

[and take it out]

[tomorrow]

This poem is said to someone who is being too bright and cheerful in the morning by someone who needs a coffee before they can be expected to be sociable. Since the pioneering work of Peter and Iona Opie in their series of studies of the children's rhymes, songs and games, from The Lore and Language of Schoolchildren (1959) to The Singing Game (1985), we have known that these kinds of language games are remarkably long-lived, although frequently adapted to capture short-lived references to pop culture, political events or the microcosm the speaker occupies. It is hardly surprising, given the geographical proximity of Swedish speaking Finland to the Torne Valley, that there would be a great deal of cross-fertilization. Here we see the insertion of "Gu" before "moron": first the lips open to allow the fricative to be formed before closing to make the plosive " $\mathrm{m}$ ". The shift of the lips demands a micro-pause and therefore forms a stress. "Gu'moron" is thus dactylic (i.e. typical of Finnish stress patterns) whereas "morgan" in the standard Swedish greeting "god morgon" is iambic.

The sharing of these distinctive rhythms, I suggest, contributes to the formation of a "we" who speak "our language" even more strongly than the metaphors and images of more complex works like Tuu, tuu, tupakkarulla. This novel is also a rare 
exception in another sense: it is meant to be read alone. The dual language of the book supports readers whose Meänkieli is not strong enough to manage the content. At the same time, the contrasts in the illustrations promote a sense of in-group belonging when reading in Meänkieli and a rejection of the majority culture in the illustrations of the Swedish version of the story. Most children's literature in Meänkieli, however, is not intended to be read alone (see Kokkola forthcoming). The sharing of the rhythms of Meänkieli generates what Ingar Brinck refers to as "social entrainment": the collective response to the rhythms of music or visual art (2017, p. 7). Brinck, like Clayton, Sager and Will (2004) shows how musical entrainment develops a sense of emotional commitment to others. In short, we are physiologically disposed to bond with those with whom we fall into phase.

As the children of the Torne Valley fall into phase with the rocking movements of their cradle songs, with their skipping and clapping rhymes, with their repetitions of the songs their grandparents were beaten for singing, they form a sense of community. They will need stories like Tии, тии tupakkarulla to understand why their parents did not grow up speaking this language with pride. They will need the activists who produce these materials to continue their work so that there will be books to read when they are older. They will need to become activists themselves if the language and culture is to flourish. But the first step is to be brave enough, like Elina in the novel, to sing in Meänkieli: "our language".

Open Access This article is distributed under the terms of the Creative Commons Attribution 4.0 International License (http://creativecommons.org/licenses/by/4.0/), which permits unrestricted use, distribution, and reproduction in any medium, provided you give appropriate credit to the original author(s) and the source, provide a link to the Creative Commons license, and indicate if changes were made.

\section{References}

Ahmed, Sara. (2006). Queer Phenomenology: Orientations, Objects, Others. Durham, NC: Duke University Press.

Ahmed, Sara. (2014). The Cultural Politics of Emotion, 2nd ed. Edinburgh: Edinburgh University Press.

Brinck, Ingar. (2017). Empathy, engagement, entrainment: the interaction dynamics of aesthetic experience. Cognitive Processing, https://doi.org/10.1007/s10339-017-0805-x.

Clayton, Martin, Sager Rebecca, and Will, Udo. (2004/2005). In Time With The Music: The concept of entrainment and its significance for ethnomusicology. ESEM Counterpoint, 11(1), 3-75.

Coats, Karen. (2013). The Meaning of Children's Poetry: A Cognitive Approach. International Research in Children's Literature, 6(2), 127-142.

Elenius, Lars. (2004). 'Ett uthålligt språk.' Nationella minoriteter och minoritetsspråk. Rapporter från riksdagen 5 [A Sustained Language]: National Minorities and Minority Languages. Stockholm: Reports from the Swedish Government 5: 75-186.

Elenius, Lars. (2006). Nationalstat och minoritetspolitik [Nationalist State and Minority Politics]. Accessed August 20, 2017 from http://www.suonttavaara.se/dokument/Karesuando\%20bilder.html.

Johansson, Monica, and Mörtlund, Mona (Eds.). (1986). Moron, Moron, Ostaks' Poron [Morning, Morning, D’you Wanna buy a Reindeer?]. Luleå: Socialstyrelsen \& Länsskolnämnden.

Kenttä, Mattias and Weintz, Erik. (1968). Lärarutbildningen och den finsktalande befolkningen $i$ Norrbotten: utredning verkställd på uppdrag av Skolöverstyrelsen. [Teacher Education and the Finnish Speaking Population of Norrbotten: An Evaluation Commissioned by the National School Board. Report 13.] Stockholm: Skolöverstyrelsen. 
Kokkola, Lydia. (forthcoming). Children's Literature in 'Our Language'. Bookbird: A Journal of International Children's Literature 55.

Korpi, Annika. (2003). Hevonen Häst. [Horse horse]. Stockholm: Norstedt.

Kruuka, Astrid. (2001). Meänkieli ja Mettä Mimmi: sainger, rim, ramsor och lekar. [Our language and Forest Mimmi: Songs, rhymes, sayings and games]. Pajala: Meänkieli på förskola, skola och fritidshem.

Lakoff, George and Johnson, Mark. (1980/2008). Metaphors We Live By. Chicago: University of Chicago Press.

Lantto-Toffe, Kristina. (1994). Tuu, tuu, tupakkarulla [Come, Come, Roll of Tobacco]. Luleå: Kaamos.

Mackey, Margaret. (2017). The Child's Reading Body. In Roxanne Harde and Lydia Kokkola (Eds.), The Embodied Child: Readings in Children's Literature and Culture (pp. 175-190). London and New York: Routledge.

Merleau-Ponty, Maurice. (1945/1996). Phenomenology of Perception. New York and London: Routledge.

Pullinger, Debbie. (2017). From Tongue to Text: A New Reading of Children's Poetry. London: Bloomsbury.

Pullinger, Debbie. (2017b forthcoming). Nursery Rhymes: Poetry, Language and the Body. In Kate Wakeley-Mulroney and Louise Joy (Eds.). The Aesthetics of Children's Poetry: A study of Children's Verse in English. London: Routledge.

Slunga, Nils. (1965). Staten och den finskspraikiga befolkningen i Norrbotten. [The State and the Finnish Speaking Population of Norrbotten.] Luleå: Tornedalica $\mathrm{nr} 3$.

Stålnacke, Aina. (1989). Missa: Kertomus Liinan viishasta kissasta. [Missa: Tales of Liina’s Wise Cat.] Överkalix: Förlaaki Kaamos.

Winsa, Birger. (1998). Language attitudes and social identity: Oppression and revival of a minority language in Sweden. No. 17. Applied Linguistics Association of Australia. 